\title{
Kinetics of Biological Treatment of Low Level Pesticide Wastewater
}

\author{
Abdel E. Ghaly and Deepika Dave \\ Department of Process Engineering and Applied Science, \\ Dalhousie University, Halifax, Nova Scotia, Canada
}

Received 2012-06-05; Revised 2012-07-02; Accepted 2012-07-02

\begin{abstract}
Pesticides are chemical substances intended to protect food crops and livestock from pests in order to promote agricultural productivity and protect public health. Contamination of soil, air and water and threat to human and animal health are the major constraints in the use of pesticides. Treatment of pesticide contaminated water is, therefore, paramount. Biological treatment provides the most economical option when compared to other treatment methods. The aim of the study was to develop a safe and effective in the farm biological treatment for low level agricultural pesticide wastewater. The degradation of the fungicide captan was evaluated under batch and continuous modes of operation with a retention time of 15 days. The initial cell number $\left(30.1 \times 10^{6}\right.$ cells $\left./ \mathrm{mL}\right)$ in the soil water mixture first declined with time during the $24 \mathrm{~h}$ reaching $15.6 \times 10^{6}$ and $11.1 \times 10^{6}$ cells $/ \mathrm{mL}$ in the batch and continuous bioreactors, respectively. This was due to the inhibitory effect of pesticide on some of the soil microbial species that had less tolerance to captan at the initial concentration of $144 \mathrm{mg} \mathrm{L}^{-1}$. Then, the microbial population started growing, reaching its maximum after 5 and 12 days from the start in the batch and continuous bioreactors, respectively. The lag period and the specific growth rate for the batch bioreactor were $22 \mathrm{~h}$ and $0.096 \mathrm{~h}^{-1}$, respectively. A captan degradation efficiency of $89.6 \%$ was achieved after 10 days in the continuous bioreactor compared to a degradation efficiency of $100 \%$ after $5 \mathrm{~d}$ in the batch bioreactor. This study showed that the effluent from the continuous bioreactor has a captan concentration of $12 \mathrm{mg} \mathrm{L}^{-1}$ which is not acceptable for livestock water according to Health Canada Guidelines. A half life of $52 \mathrm{~h}$ is observed in the batch bioreactor.
\end{abstract}

Keywords: Pesticide, Captan, Inhibition, Half Life Time, Biodegradation, Bioreactor, Soil Microbes, Specific Growth Rate

\section{INTRODUCTION}

Pesticides provide the primary means for controlling organisms (fungi, bacteria, mites, insect's rodents, nematodes and undesirable plants) that compete with man for food and fibre or cause injury to man, livestock and crops. They are classified based on the pest they control into several classes: fungicides, bactericides, acaricides, insecticides, rodenticides, nematicides and herbicides. The worldwide pesticide expenditures in 2007 were 39.4 billion dollars accounting for 2.37 billion $\mathrm{kg}$ of pesticide. Pesticide expenditures account for $13-22 \%$ of the total cost of production per hector. However, for every dollar spent on pesticide farmers receive an additional of \$4-33 in revenue from increased yield, depending upon crop rotation and year of production (Horowitz and
Lichtenberg, 1993; Osteen and Livingstion, 2007).

Pesticides played a vital role in increasing agricultural production and permitting the economic production of wide ranges of vegetable, fruit, cereal, forage, fibre and oil crops which now constitute a large part of successful agricultural industry in many countries. They lower crop losses, increase revenue to farmers because of the additional marketable yield obtained with their use and thus lower the cost of production per unit output (Horowitz and Lichtenberg, 1993). Other benefits of pesticides includes: (a) reduced uncertainty of crop loss from pests, (b) increased profit to farm input suppliers (machinery, fertilizer, chemicals and seed companies) from increased sale, (c) benefit to consumers through decreased price of raw foods or improved quality of food products and (d) benefit to 
society as whole (farmers, consumers, farm suppliers, food processors) from increased employment opportunities and expanded export of food products (Oerke and Dehne, 2004; Cooper and Dobson, 2007).

However, pesticides are toxic chemicals that can adversely affect people, pets, livestock, wildlife and desirable plants in addition to the pests they are intended to destroy (Centner, 1998; Wilson and Tisdell, 2001; Ridgway et al., 1978). Pesticide residues remain in the containers and application equipment after pesticides are applied to target areas. These residues are removed from applicators by rinsing with water resulting in the formation of a toxic wastewater that represents a disposal problem for many farmers (Kearney et al., 1988). Currently, disposal of pesticide wastewater is carried out by several methods including (a) land cultivation, (b) dumping on land, in ditches, in lagoons and in soil pits and in extreme cases in sewers and streams near the rinsing operation, (c) use of evaporation ponds and (d) land filling (Al Hattab and Ghaly, 2012). These methods of disposal are totally unsafe, as the surface run off will reach streams, rivers and lakes and the infiltration of the wastewater into the local soil will eventually end up in ground water. The ecological impact of unsafe disposal of pesticides can be significant depending on the type and concentration of pesticides in the wastewater. Therefore, pesticide containing wastewater must be properly treated. The treatment methods currently used for pesticide containing wastewater include (a) incineration, (b) chemical treatment such as $\mathrm{O}_{3} / \mathrm{Uv}$ oxidation, Fenton oxidation and hydrolysis (c) physical treatment using inorganic and organic absorbents and (d) biological treatment such as phytoremediation, composting and bioaugmentation. These treatment methods either require land or are expensive and suffer from variability of effectiveness (Balestra and Misaghi, 1997; Winterlin et al., 1989; Al Hattab and Ghaly, 2012).

The aim of the study was to develop a safe and effective on farm biological treatment for low level agricultural pesticide wastewater and to evaluate its mode of operation (batch vs continuous).

\section{EXPERIMENTAL APPARATUS}

The pesticide treatment system (Fig. 1) consisted of pesticide contaminated wastewater feeding system, 2 bioreactors (batch and continuous) and 2 effluent collection tanks.

\subsection{Bioreactors}

Two identical bioreactors (each of approximately 15.7 L volume) were constructed from Plexiglas material and designed to hold $10 \mathrm{~L}$ each of soil-water- pesticide mixture plus a head space. Each bioreactor was constructed of $1.0 \mathrm{~cm}$ thick Plexiglas cylinder of $20 \mathrm{~cm}$ diameters and $50 \mathrm{~cm}$ height. The bottom of the cylinder was made of $1.0 \mathrm{~cm}$ thick circular Plexiglas plate of 20 $\mathrm{cm}$ diameter which was glued to the cylinder. The top lid was made of $1.0 \mathrm{~cm}$ thick circular plate of $22 \mathrm{~cm}$ diameter which was secured into the cylinder using six stainless steel screws and wing nuts. The lid had three $1.5 \mathrm{~cm}$ diameters holes: one in the center for the mixing shaft and the other two holes were used for the wastewater input and air exhaust. The reactor contents were mixed using as $55 \mathrm{rpm}$ induction motor (Japan Servo Company, Tokyo, Japan) which was mounted on the reactor lid and connected to a $1.5 \mathrm{~cm}$ diameter mixing shaft. A $15 \mathrm{~cm}$ diameter propeller was placed on the shaft at $2 \mathrm{~cm}$ from the diffuser. An air inlet port was provided at the bottom of each cylinder and was fitted with $20 \mathrm{~mm}$ PVC elbow. An air diffuser (Dynamic Aqua-Supply Ltd., Sydney, Canada) was attached to the elbow inside the cylinder. The diffuser diameter and height were 15 and $25 \mathrm{~mm}$, respectively. The other end of the elbow was connected to Tygon tubing which connected the diffuser to the air supply unit that consisted of an air compressor (3/4 HP Shanborn model MCIFC 75-715), a pressure regulator (Model ZFMQ000PR, Millipore Pressure Regulator, Massachusetts, USA) and a flow meter (Model 60648, Cole Parmer, Chicago, Illinois, USA).

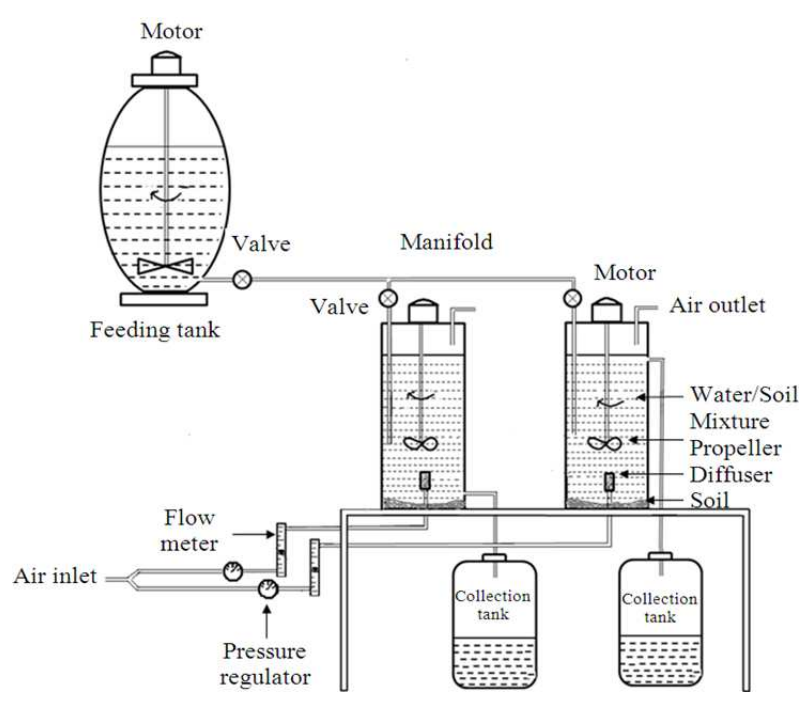

Fig. 1. Experimental apparatus 


\subsection{Feeding System}

The wastewater feeding system consisted of storage tank and a distribution manifold with a set of three values. A $100 \mathrm{~L}$ plastic tank was used to store the waste water. The tank was fitted with a stirring paddle driven by a 1/12 HP electric motor (Model 5SCP10FG17AX, General Electric, Mississauga, Ontario) mounted on the tank cover. A feeding and ventilation ports were also provided on the tank cover. A $5 \mathrm{~cm}$ ball valve was connected to the fitting on the tank from one side and to the manifold from the other side. The other two valves on the manifold controlled the flow into the bioreactors.

\subsection{Collection Tanks}

Two 25 L plastic carboys (Cat No.02-961B) Fishers Scientific, Montreal, Quebec) were used to collect the effluent from the bioreactors.

\section{MATERIALS AND METHODS}

\subsection{Pesticide}

The fungicide Captan 80- WP $\left(\mathrm{C}_{9} \mathrm{H}_{8} \mathrm{ClNO}_{2} \mathrm{~S}\right)$ was chosen for this experiment because it is one of the most heavily used pesticide in the Province of Nova Scotia. The properties and structure of captan 80 -WP are shown in Table 1. It is classified as a protectant eradicant fungicide and is one of the most used pesticides today due to its effectiveness in controlling a wide variety of fungal diseases (Table 2). The formulation of this pesticide is a microfine wettable powder containing $80 \%$ active ingredient (75.5\% $\mathrm{N}$-[trichloromethyl)thio]-4-cyclohexene-1,2-dicarboaimi de and $4.3 \%$ related derivatives). The balance $(20 \%)$ is made of mineral dust and wetters dispersants. This formulation is preferred by many growers since it minimizes visible residue and thus provides an excellent vegetable and fruit finish.

\subsection{Soil}

The soil used in this experiment was obtained from an agricultural field in Stewiack, Nova Scotia. It was obtained from a field where $50 \mathrm{~kg} /$ acre of urea, 75 $\mathrm{kg} / \mathrm{acre}$ of 17-17-17 NPK fertilizers and $1500 \mathrm{~kg}$ of liquid manure were applied annually. The top trash coves of the soil was scraped away and the soil was removed by a shovel from the top $30 \mathrm{~cm}$ and placed in a heavy duty (16 $\mathrm{m}$ thick) Polyethylene bag and transported to the waste management laboratory. The soil was used as a source of a mixed microbial culture.
Table 1. Chemical formula and structure for captan (WAKB, 2011; Aldrich, 2011)

\begin{tabular}{lll}
\hline Chemical Name & Properties & Structure \\
\hline 3a,4, 7, 7a-tetrah & Powerful protectant \\
ydro-2-[\{tricholoro & fungicide Solid \\
methylthio\}]- & (yellow amphous \\
1H-isoindole- & powder) & \\
$1,3(2 \mathrm{H}$ )-dione & Insoluble in water & \\
& Molecular Weight $=$ & $\mathrm{C}_{9} \mathrm{H}_{8} \mathrm{Cl}_{3} \mathrm{NO}_{2} \mathrm{~S}$ \\
& $300.59 \mathrm{~g} \mathrm{moL}-\mathrm{p}$ \\
& Boiling Point $=314^{\circ} \mathrm{C}$ \\
& Melting Point $=172^{\circ} \mathrm{C}$ \\
& Density $=1.74 \mathrm{~g} \mathrm{~mL}^{-1}$ \\
& Flash Point $=143^{\circ} \mathrm{C}$ \\
& Carcinogen \\
& Moderate eye irritant \\
& Skin sensitizer \\
& Toxic by inhalation \\
& No evidence of phototoxicity \\
&
\end{tabular}

Table 2. Crops and fungal diseases registered for Captan 80-WP

\begin{tabular}{ll}
\hline Crop & Fungal diseases treated \\
\hline Apple & Scab, Sooty Bloch, Fly Speck, \\
& Brook's Spot, Bitter Rot, Black \\
& Rot, Bull's Eye Rot \\
Apricot & Brown Rot \\
Cherries & Brown Rot, Leaf Spot \\
Peach & Brown Rot, Scab \\
Pear & Scab, Soty Bloch \\
Plum & Black Rot, Brown Rot \\
Grape & Dead Arm, Dawny Mildew, Black Rot \\
Raspberry & Fruit Rot \\
Blackberry & Fruit Rot \\
Loganberry & Cane Spot, Fruit Rot, Leaf Spot, Spur Blight \\
Blueberry & Fruit Rot, Mummy Berry \\
Strawberry & Gray Mold Rot, Leaf Spot \\
Rhubarb & Leaf Rot \\
Cucumber & Anthracnose, Scab \\
Tomato & Anthracnose, Septoria, Leaf Spot \\
\hline
\end{tabular}

\section{EXPERIMENTAL PROCEDURE}

\subsection{Experimental Protocol}

Two experiments were carried out: a batch experiment which was run for 15 days and a continuous experiment which was run with a retention time of 15 days. Eighteen grams of captan dust (14.4 g active material) were added into the water $(100 \mathrm{~L})$ in the feeding tank to provide a captan concentration of $144 \mathrm{mg}$ $\mathrm{L}^{-1}$ in the wastewater. The initial soil:water ratio in the bioreactors was $1: 3$. The soil $(0.75 \mathrm{~L})$ was placed in the bioreactors and the water $(2.25 \mathrm{~L})$ was then added. The batch bioreactor was filled up to the $10 \mathrm{~L}$ level. For the continuous bioreactor, the feeding pump was adjusted to provide a flow rate of $0.46 \mathrm{~mL} /$ minute in order to achieve the 15 day retention time. The mixing motor and the air compressor were turned on. The air flow rate was set at $10 \mathrm{~L}^{-1} \mathrm{~min}^{-1}(1 \mathrm{v} / \mathrm{v} / \mathrm{min})$ using the flow meter. Samples were collected from each bioreactor on a daily 
basis and vacuum filtered using a coarse filter paper (P8 Grade, Fisher Scientific, Canada) to remove any soil particles. The filtered samples were used for plate count and pesticide analyses.

\subsection{Plate Count}

The plate count was performed on the initial soil water mixture before the addition of pesticide and on the samples collected from the bioreactors. For each sample, 5 test tubes were filled with $9.9 \mathrm{ml}$ of pepton. A 1:100 dilution was prepared by pipetting $0.1 \mathrm{~mL}$ of the initial dilution into the first tube. This was then mixed well and $0.1 \mathrm{~mL}$ was placed on an agar lined Petri dish and spread over the entire surface using a glass wand. The wand was cleaned with reagent alcohol and flamed before each use. From the diluted tube, a $0.1 \mathrm{~mL}$ was transferred to another tube contains $9.9 \mathrm{~mL}$ pepton to produce a dilution of 1:1000. The mixture was mixed well and 0.1 $\mathrm{mL}$ was transferred into another Petri dish. The same procedure was repeated to produce final dilutions of 1 : $100, \quad 1: 1000, \quad 1: 10000, \quad 1: 10000, \quad 1: 100000$ and 1:1000000. Three plates of each dilution were carried out. All the inoculated Petri dishes were then placed in a temperature control incubator (Model 2020, Sheldon Manufacturing Inc, Oregon, USA) at $35^{\circ} \mathrm{C}$. The plates were examined after $24 \mathrm{~h}$ and the dilution that produced reasonable countable number of calories were selected. The total colonies on each Petri dish were calculated using a plate counter (Model 7-901, Fisher Colony Counter, New York, USA). The population was then determined by multiplying the number of colonies by the dilution factor.

\subsection{Pesticide Analysis}

Three $\mathrm{ml}$ of the sample were mixed with $3 \mathrm{~mL}$ of the hexane/ether solvent (95:5) in a test tube. The test tube was then caped and heated at $115^{\circ} \mathrm{C}$ for $30 \mathrm{~min}$ followed by a cooling period to a temperature below $0^{\circ} \mathrm{C}$. When the sample was frozen, the liquid solvent was withdrawn from the top. $2 \mu \mathrm{L}$ of this sample were then used for injection into a gas chromatographer (5890 series II, Hewlett Packard, California, USA). The initial and final concentrations of captan in each unit were determined. The chromatograph was calibrated by injecting $1.0 \mu \mathrm{L}$ of the extracted captan mixture into the $25 \mathrm{~m} \mathrm{X} 0.2 \mathrm{~mm}$ capillary column. $1.0 \mu \mathrm{L}$ of the extracted sample was then injected into the column. The column temperature was first maintained at $40^{\circ} \mathrm{C}$ for three minutes and then increased at the rate of $10^{\circ} \mathrm{C}$ per minute until a temperature of $270^{\circ} \mathrm{C}$ was attained. The column was then maintained at $270^{\circ} \mathrm{C}$ for five minutes. The injection port was set at $25^{\circ} \mathrm{C}$ while the flame inonization detector was set at $250^{\circ} \mathrm{C}$. Helium was used as a carrier gas at a flow rate of $1.2 \mathrm{~mL}^{-1} \mathrm{~min}$.

\section{RESULTS AND DISCUSSION}

\subsection{Microbial Growth}

The growth of the mixed microbial population in the batch and continuous bioreactors are shown in Fig. 2 . The initial cell number in the soil water mixture in both bioreactors was $30.1 \times 10^{6}$ cells $/ \mathrm{mL}$. The number of cells first declined with time during the first $24 \mathrm{~h}$ reaching $15.6 \times 10^{6}$ cells $/ \mathrm{mL}$ in the batch bioreactor and $11.1 \times 10^{6}$ cells/mL in the continuous bioreactor. This was due to the inhibitory effect of pesticide on some of the soil microbial species that had less tolerance to captan at the initial concentration of $144 \mathrm{mg} \mathrm{L}^{-1}$. The lower value $(29 \%$ lower) observed in the continuous bioreactor compared to that of the batch bioreactor was due to the loss of microbes from that bioreactor with the effluent.

Wainwright and Pugh (1975) reported declined trend of bacterial population (from $16.5 \times 10^{6}$ to $14 \times 10^{6}$ cells) during first $48 \mathrm{~h}$ after application of $25 \mu \mathrm{g} / \mathrm{g}$ captan to field soils. Agnihotri (1971) reported a significant reduction (from $2.3 \times 10^{5}$ to $0.4 \times 10^{5}$ cells) of the actinomycete population in fresh soil by the $7^{\text {th }}$ day after application of 125 ppm captan. Martinez-Toledo et al. (1998) studied the effects of captan concentration (2.0-10.0 kg/ha) on microbial function in four agricultural soils under aerobic conditions and reported significant decreases in total culturable fungal populations, nitrifying bacteria and aerobic nitrogen fixing bacteria during the first 14 days. Piotrowska-Seget et al. (2008) reported $46 \%$ reduction (from $7.8 \times 10^{5}$ to $4.2 \times 10^{5}$ ) in bacterial population during the first 10 days after application of captan at a rate of $8.5 \mathrm{mg} / \mathrm{g}$ of soil and observed increase (from $4.2 \times 10^{5}$ to $7.6 \times 10^{5}$ ) in population after 94 days which was about $97.43 \%$ of the original population. Similar results were reported with malathion (Shan et al., 2009), chlorpyrifos alone and in combination with chlorothalonil (Xiaoqiang et al., 2008), dichlorvos (Ning et al., 2010), 2-(2-methyl-4-chlorophenoxy)propionic acid (MCPP) (Lipthay et al., 2003; Tuxen et al., 2006), phenoxy acids (Chilton et al., 2005), 2,4-D (Broholm et al., 2001), 2-(2,4-dichlorophenoxy)propionic acid (Lipthay et al., 2003).

The four phases normally encountered in a batch operation (lag, exponential growth, stationary growth and death phases) were observed with the batch bioreactor. After the initial lag period, the microbial population in the batch bioreactor started to increase with time reaching a maximum of $113.9 \times 10^{6}$ after 120 $\mathrm{h}$ ( 5 days from the start), remained relatively constant till the $240 \mathrm{~h}$ (for 5 days) and then started to decline. The microbial population of the continuous bioreactor also increased but at slower rate than that of the batch bioreactor due to the continuous loss of microbes from the bioreactor with the effluent. 


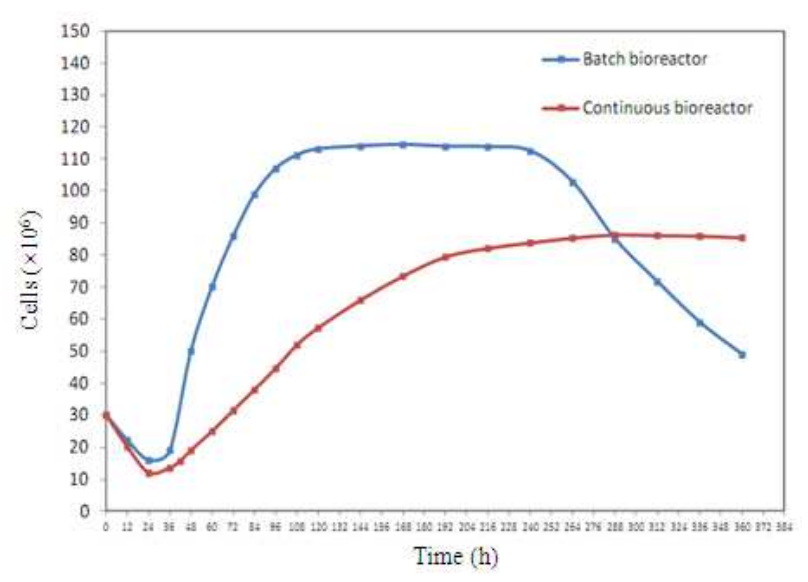

Fig. 2. Microbial growth

It reached a steady state condition after $288 \mathrm{~h}(12 \mathrm{~d}$ from the start) when the rate of microbial growth in the bioreactor was equal to the rate of microbial loss from the bioreactor with the effluent. The microbial population in the continuous bioreactor at the steady state was $86.5 \times 10^{6}$ cells $/ \mathrm{mL}(75.94 \%$ of that in the batch bioreactor).

The lag period and specific growth rate were determined from the batch operation data according to the procedure described by Ghaly et al. (1989) as shown in Fig. 3. The lag period and the specific growth rate were $22 \mathrm{~h}$ and $0.096 \mathrm{~h}^{-1}$, respectively. Radianingtyas et al. (2003) reported $18 \mathrm{~h}$ lag period and $0.014 \mathrm{~h}^{-1}$ specific growth rate while degrading 4-choloroaniline $(1 \mathrm{mM})$ in a batch reactor with a bacterial consortium comprising four different species isolated from an Indonesian agricultural soil. Lappin et al. (1985) reported $18 \mathrm{~h}$ lag period and $0.09 \mathrm{~h}^{-1}$ specific growth rate while degrading mecoprop $\left(1 \mathrm{gm} \mathrm{L}^{-1}\right)$ in a batch reactor with a microbial community isolated from wheat root systems. Rhee et al. (1997) were able to demonstrate pyridine degradation (3 $\mathrm{mM}$ ) in a batch reactor and reported $13 \mathrm{~h}$ lag period and $0.08 \mathrm{~h}^{-1}$ specific growth rate using denitrifying bacteria isolated from industrial wastewater.

The lag period and net specific growth rate $\left(\mu_{\text {net }}\right)$ was also determined for the continuous bioreactor during the initial nonsteady state period using the same procedure as shown in Fig. 4. The lag period and net specific growth rate for the continuous bioreactor were $26 \mathrm{~h}$ and $0.045 \mathrm{~h}^{-1}$, respectively. Krishna and Philip (2009) conducted studies on biodegradation of carbofuran at a concentration of $150 \mathrm{mg} \mathrm{L}^{-1}$ in a continuous reactor and reported $48 \mathrm{~h}$ lag period and $0.3928 \mathrm{~d}^{-1}$ specific growth rate using carbofuran enriched cultures.

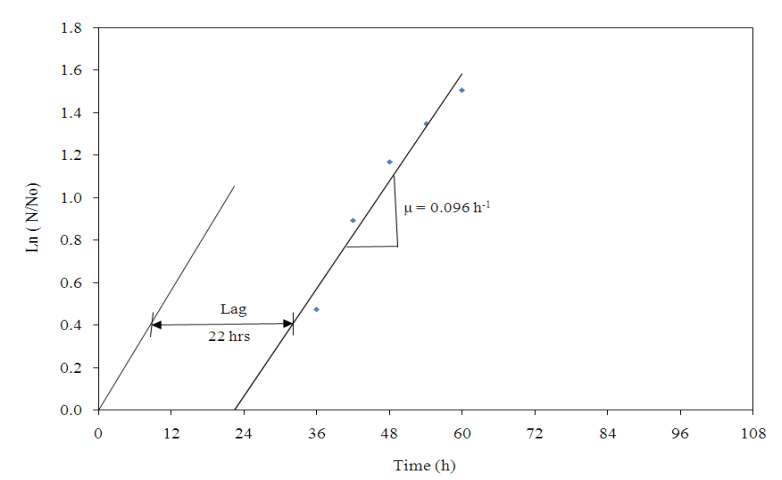

Fig. 3. Determination of the lag period and specific growth rate in the batch bioreactor

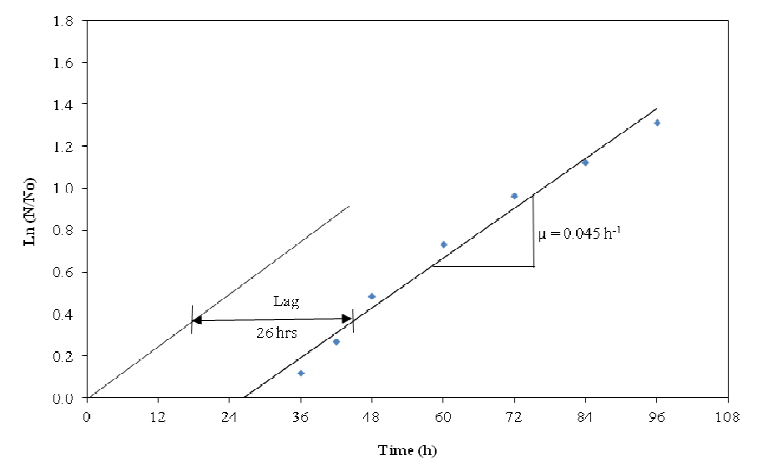

Fig. 4. Determination of the lag period and net specific growth rate in the continuous bioreactor

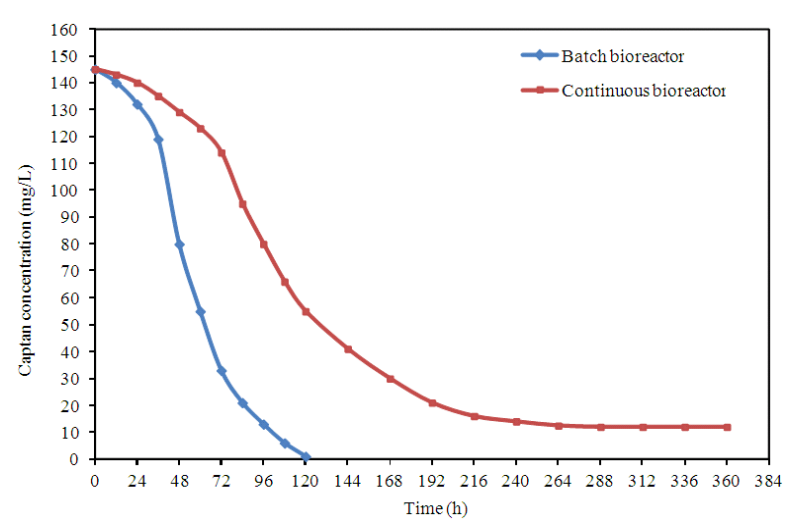

Fig. 5. Pesticide concentration in batch and continuous bioreactors

The net specific growth rate $\left(\mu_{\text {net }}\right)$ in the continuous bioreactor is defined as follows:

$\mu_{\text {net }}=\mu-k_{r}$

where:

$\mu \quad=$ The specific growth rate $\left(\mathrm{h}^{-1}\right)$ 


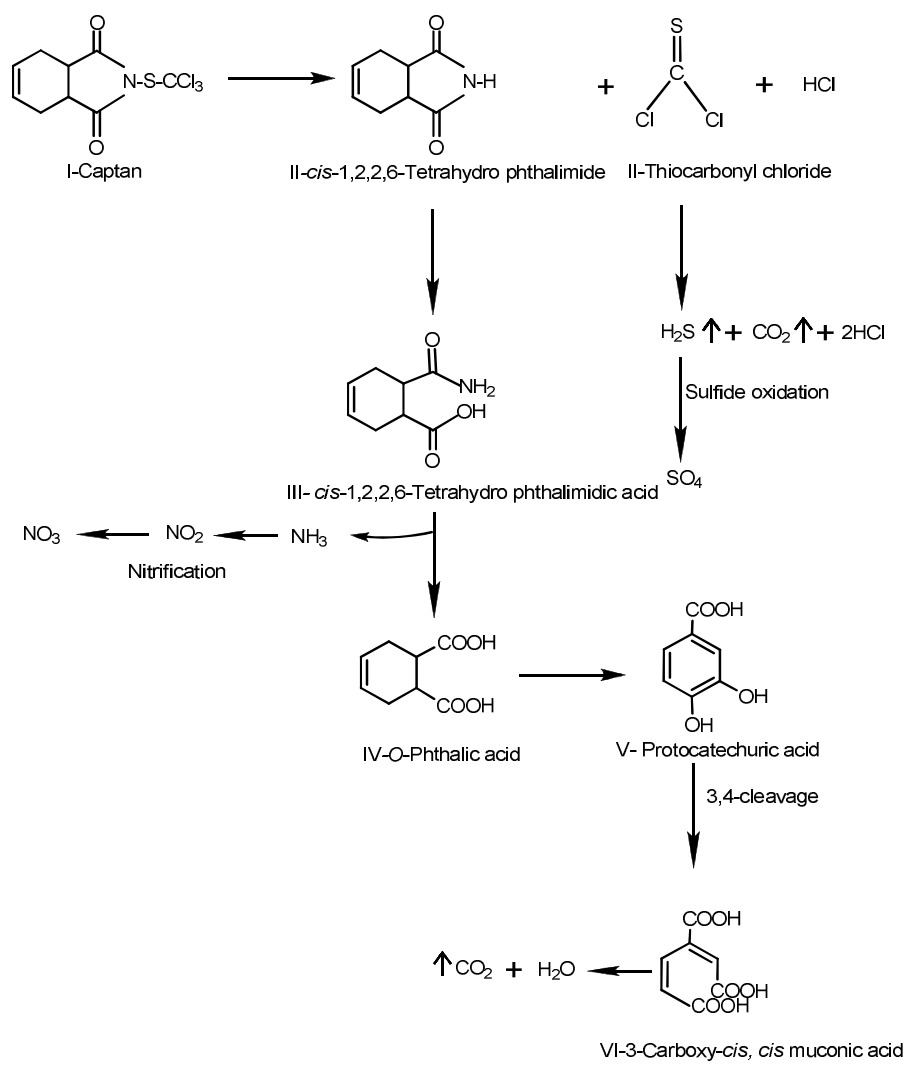

Fig. 6. Pathway for the degradation of fungicide captan under aerobic condition (Modified from Megadi et al., 2010)

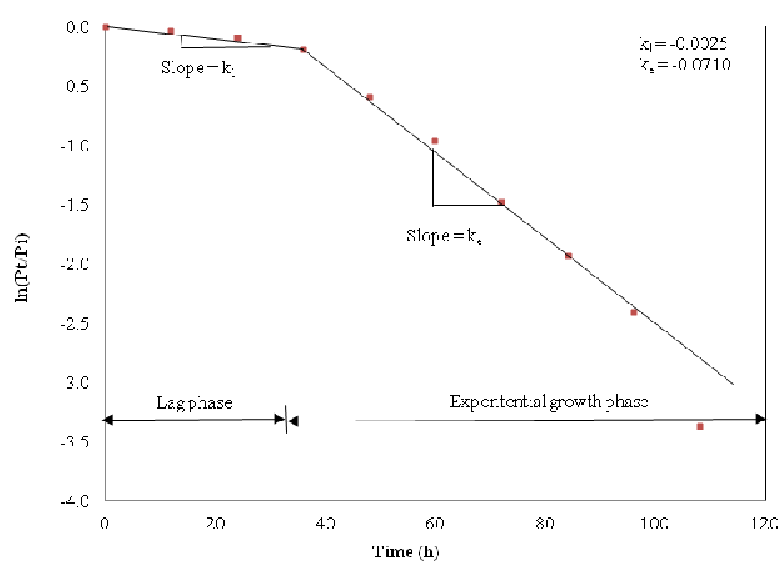

Fig. 7. Determination of rate constant $\mathrm{k}$

$\mu_{\text {net }}=$ The net specific growth rate $\left(\mathrm{h}^{-1}\right)$

$\mathrm{k}_{\mathrm{r}}=$ The cell removal rate with effluent $\left(\mathrm{h}^{-1}\right)$

The results indicated that the rate of microbial loss with the effluent $\left(\mathrm{k}_{\mathrm{r}}\right)$ was $0.051 \mathrm{~h}^{-1}$.

\subsection{Pesticide Degradation}

The pesticide concentrations in the effluent samples taken from the batch and continuous biorearctors overtime are shown in Fig. 5. The pesticide concentration in the batch bioreactor started to decline with time reaching zero value after $120 \mathrm{~h}(5 \mathrm{~d})$ from the start. Also, the pesticide concentration in the effluent of the continuous bioreactor declined with time reaching a constant value of $15 \mathrm{mg} \mathrm{L}^{-1}$ after $288 \mathrm{~h}(10 \mathrm{~d})$. Thus, a removal efficiency of $89.6 \%$ was achieved after 10 days with the continuous bioreactor compared to a removal efficiency of $100 \%$ after $5 \mathrm{~d}$ with the batch bioreactor. Megadi et al. (2010) reported a complete degradation of fungicide captan after 6 days during growth of Bacillus circulans in the Mineral Salt Medium (MSM) containing $0.1 \%$ captan. Buyanovsky et al. (1988) reported 33\% degradation of captan (with an initial concentration of 50 $\mathrm{mg} \mathrm{L}^{-1}$ ) after 2 weeks (including lag phase of 2 days) of incubation with soil bacteria, no further degradation of captan was observed after the 2 weeks period. The maximum permissible value for captan and metabolites in livestock water is set $13 \mu \mathrm{g} \mathrm{L}^{-1}$ (HC, 2010). However, 
a Canadian drinking water quality guideline for captan has not been developed (HC, 2010). The batch bioreactor used in the study achieved $100 \%$ removal of captan while the effluent from continuous bioreactor contained $15 \mathrm{mg} \mathrm{L}^{-1}$ which is not acceptable for livestock water.

Biological degradation of pesticides refers to the use of microorganisms to destroy those chemicals in solid or liquid wastes into harmless by products. The aerobic biological treatment relies on microbial activity and aeration efficiency. Microbes that naturally occur in soil increased significantly in number and began to biodegrade pesticide in this study. The microbes utilized the pesticide as bioavailable carbon source for energy (respiration) and synthesis (growth) of microbial cells according to the following equations:

\section{Energy}

Organic matter $+\mathrm{O}_{2} \stackrel{\text { Microbes }}{\longrightarrow} \mathrm{CO}_{2}+\mathrm{H}_{2} \mathrm{O}+$ other products + Heat

Synthesis

Organic matter $+\mathrm{NH}_{4} \stackrel{\text { Microbes }}{\longrightarrow}$ more microbes

The proposed pathway for the degradation of captan is shown in Fig. 6. The soil microbial population used in this study contained microorganisms capable of utilizing the carbon, chloride, nitrogen and sulfur found in captan $\left(\mathrm{C}_{9} \mathrm{H}_{8} \mathrm{Cl}_{3} \mathrm{NO}_{2} \mathrm{~S}\right)$ under aerobic condition into carbon dioxide $\left(\mathrm{CO}_{2}\right)$, water $\left(\mathrm{H}_{2} \mathrm{O}\right)$, chloride $(\mathrm{Cl})$, nitrate $\left(\mathrm{NO}_{3}\right)$ and sulphate $\left(\mathrm{SO}_{4}\right)$ and obtain the energy required for growth according to the following equation (Swanner and Templeton, 2011; Megadi et al., 2010; Munch et al., 1996):

$\mathrm{C}_{9} \mathrm{H}_{8} \mathrm{Cl}_{3} \mathrm{NO}_{2} \mathrm{~S}+8.5 \mathrm{O}_{2} \stackrel{\text { Soil microbes }}{\longrightarrow} 9 \mathrm{CO}_{2}+\mathrm{H}_{2} \mathrm{O}+3 \mathrm{HCl}+\mathrm{NH}_{3}+\mathrm{H}_{2} \mathrm{~S}+\Delta \mathrm{E}(4)$

The captan degradation process takes place in several steps. In the first step, captan is converted into cis-1,2,3,6- tetrahydro phthalimide, thiocarbonyl chloride and hydrochloric acid. In the second, step cis-1,2,3,6-tetrahydro pthalimide is converted into cis-1,2,3,6-tetrahydro pthalimidic acid and thiocarbonyl chloride is converted into $\mathrm{H}_{2} \mathrm{~S}, \mathrm{CO}_{2}$ and $\mathrm{H}_{2} \mathrm{O}$. In the third step, the $c i s$-1,2,3,6-tetrahydro pthalimidic acid is converted into O-phthalic acid and ammonia. In the forth step, the O-phthalic acid is converted into protocatechuic acid. In the fifth step, the protocatechuic acid is converted into 3carboxy-cis,cis muconic acid which is oxidized to $\mathrm{CO}_{2}$ and $\mathrm{H}_{2} \mathrm{O}$. The $\mathrm{NH}_{3}$ is converted into $\mathrm{NO}_{3}$ by the nitrifying bacteria while the $\mathrm{H}_{2} \mathrm{~S}$ is converted into $\mathrm{SO}_{4}$ by the hydrogen sulphide reducing bacteria as follows:

$$
\begin{aligned}
& \mathrm{NH}_{3}+2 \mathrm{O}_{2} \stackrel{\text { Nitrifies }}{\longrightarrow} \mathrm{NO}_{3}^{-}+\mathrm{H}_{2} \mathrm{O}+\mathrm{H}^{+}+\Delta \mathrm{E} \\
& \mathrm{H}_{2} \mathrm{~S}+2 \mathrm{O}_{2} \stackrel{\text { Hydrogen sulfide reducing bacteria }}{\longrightarrow} \mathrm{SO}_{4}^{-2}+2 \mathrm{H}^{+}+\Delta \mathrm{E}
\end{aligned}
$$

The biodegradation of organic substrates such as pesticides in a batch system can be described by the following equation:

$P_{t}=P_{o} e^{-k t}$

where:

$P_{t}=$ The concentration of pesticide at the time $t\left(\mathrm{mg} \mathrm{L}^{-1}\right)$

$\mathrm{P}_{\mathrm{o}}=$ The initial concentration of pesticide $\left(\mathrm{mg} \mathrm{L}^{-1}\right)$

$\mathrm{k}=$ The rate constant $\left(\mathrm{h}^{-1}\right)$

$\mathrm{t}=$ The time $(\mathrm{h})$

A plotting of $\ln \left(\mathrm{P}_{\mathrm{t}} / \mathrm{P}_{0}\right)$ versus time $(\mathrm{t})$ yields straight line with a slope equal $\mathrm{k}$. However, plotting the data obtained from the batch bioreactor did not fit a straight line for the entire period. The results (Fig. 7) showed different degradation rates for the lag period $\left(0.0025 \mathrm{~h}^{-1}\right)$ and exponential growth period $\left(0.71 \mathrm{~h}^{-1}\right)$. It appears from the results that the microorganisms are able to utilize captan as a source of carbon and energy for maintenance during the lag period. Karpouzas et al. (2005) reported $25 \%$ degradation of cadusafos (at an initial concentration of $12 \mathrm{mg} \mathrm{L}^{-1}$ ) during the lag period of $30 \mathrm{~h}$ after inoculation of Flavobacterium sp. and Sphingomonas sp. (isolated from cadusafos contaminated soil) which was followed by gradual increases in bacterial populations. (reaching $3 \times 10^{6}$ and $8 \times 10^{6}$ cells $/ \mathrm{mL}$ for the Flavobacterium and the Sphingomonas sp. in $72 \mathrm{~h}$, respectively) that result in complete degradation of cdusafos by both isolates in $78 \mathrm{~h}$. Karpouzas and Walker (2000) reported a 30\% degradation of ethoprophos (initial concentration of $100 \mathrm{mg} \mathrm{L}^{-1}$ ) after inoculation of Pseudomonas putida (isolated from ethoprophos contaminated soil) with a mineral salts Medium Supplemented with Nitrogen (MSMN) in the first $33 \mathrm{~h}$ and observed complete degradation after $50 \mathrm{~h}$. In this study, $8.2 \%\left(12 \mathrm{mg} \mathrm{L}^{-1}\right)$ of the captan in the batch bioreactor was degraded during the lag period of $22 \mathrm{~h}$ and complete degradation was achieved in $120 \mathrm{~h}$.

Leoni et al. (1992) reported a captan half life of 3.6 days in an activated sludge system, Hermanutz et al. (1973) reported captan half lives of $7 \mathrm{~h}$ at $12^{\circ} \mathrm{C}$ and $1 \mathrm{~h}$ at $25^{\circ} \mathrm{C}$ in Lake Superior. Ghaly et al. (2007) reported primiphos-methyle half life of $25 \mathrm{~h}$ in composting system (at $50-60^{\circ} \mathrm{C}$ ). In this study, a captan half life of $52 \mathrm{~h}$ was observed for the batch bioreactor. 


\section{CONCLUSION}

The initial cell number $\left(30.1 \times 10^{6}\right.$ cells $\left./ \mathrm{mL}\right)$ in the soil water mixture first declined with time during the first 24 $\mathrm{h}$ reaching $15.6 \times 10^{6}$ and $11.1 \times 10^{6}$ cells $/ \mathrm{mL}$ in the batch and continuous bioreactors, respectively. This was due to the inhibitory effect of pesticide on some of the soil microbial species that had less tolerance to captan at the initial concentration of $144 \mathrm{mg} \mathrm{L}^{-1}$. The results indicated that microbial population reached its maximum after 5 and 12 days from the start in batch and continuous bioreactors, respectively. The lag period and the specific growth rate for the batch bioreactor were $22 \mathrm{~h}$ and 0.096 $\mathrm{h}^{-1}$, respectively. Captan degradation efficiency of $89.6 \%$ was achieved after 10 days in the continuous bioreactor compared to a degradation efficiency of $100 \%$ after $5 \mathrm{~d}$ in the batch bioreactor. A half life of $52 \mathrm{~h}$ was observed in the batch bioreactor. This study showed that the batch mode of operation completely removed captan while the effluent from the continuous bioreactor had a captan concentration of $12 \mathrm{mg} \mathrm{L}^{-1}$ which is not acceptable for livestock water according to Health Canada Guidelines.

\section{ACKNOWLEDGEMENT}

This research was funded by the Natural Science and Engineering Research Council (NSERC) of Canada.

\section{REFERENCES}

Agnihotri, V.P., 1971. Persistence of captan and its effects on microflora, respiration and nitrification of a forest nursery soil. Can. J. Microbiol., 1: 377-383. PMID: 5551317

Al Hattab, M.T. and A.E. Ghaly, 2012. Sequential remediation processes for a low level pesticide wastewater. J. Environ. Protection, 3: 150-163. DOI: 10.4236/jep.2012.32019

Balestra, G.M. and I.J. Misaghi, 1997. Increasing the efficiency of the plate counting method for estimating bacterial diversity. J. Microbiol. Methods, 30: 111-117 DOI: 10.1016/S0167-7012(97)00056-0

Broholm, M.M., K. Rugge, N. Tuxen, A.L. Hojberg and H. Mosbaek et al., 2001. Fate of herbicides in a shallow aerobic aquifer: A continuous field injection experiment (Vejen, Denmark). Water Resources Res., 37: 3163-3163. DOI: 10.1029/2000WR000002

Buyanovsky, G.A., G.J. Pieczonka, G.H. Wagner and M.L. Fairchild, 1988. Degradation of captan under laboratory conditions. Bull. Environ. Contamination Toxicol., 40: 689-695. DOI: 10.1007/BF01697516
Centner, T.J., 1998. Unwanted agricultural pesticides: state disposal programs. J. Environ. Q., 27: 736-742. DOI: $10.2134 /$ jeq1998.00472425002700040002x

Chilton, P.J., M.E. Stuart, D.C. Gooddy, R.J. Williams and A.C. Johnson, 2005. Pesticide fate and behaviour in the UK chalk aquifer and implications for groundwater quality. Quarterly J. Eng. Geol. Hydrogeol., 38: 65-65. DOI: $10.1144 / 1470-9236 / 04-014$

Cooper, J. and H. Dobson, 2007. The benefits of pesticides to mankind and the environment. Crop Protection, 26: 1337-1348. DOI: 10.1016/j.cropro.2007.03.022

Lipthay, J.R.D., N. Tuxen, K. Johnsen, L.H. Hansen and H.J. Albrechtsen et al., 2003. In situ exposure to low herbicide concentrations affects microbial population composition and catabolic gene frequency in an aerobic shallow aquifer. Applied Environ. Microbiol., 69: 461-467. PMID: 12514028

Ghaly, A.E., F. Alkoaik and A. Snow, 2007. Degradation of pirimiphos-methy 1 during thermophilic composting of greenhouse tomato plant residues. Can. Biosyst. Eng., 49: 1-11.

Ghaly, A.E., R. Kok and J.M. Ingrahm, 1989. Growth rate determination of heterogeneous microbial population in swine manure. Applied Biochem. Biotechnol., 22: 59-78. DOI: 10.1007/BF02922697

HC, 2010. Guidelines for Canadian Drinking Water Quality: Guideline Technical Document. 1st Edn., Health Canada, Canada, ISBN-10: 1100105085, pp: 82.

Hermanutz, R.O., L.H. Mueller and K.D. Kempfert, 1973. Captan toxicity to fathead minnows (Pimephales promelas), bluegills (lepomis macrochirus) and brook trout (Salvelinus fontinalis). J. Fisheries Res. Board Canada, 30: 1811-1817. DOI: 10.1139/f73-291

Horowitz, J.K. and E. Lichtenberg, 1993. Insurance, moral hazard and chemical use in agriculture. Am. J. Agric. Econ., 75: 926-935. DOI: 10.2307/1243980

Karpouzas, D.G. and A. Walker, 2000. Factors influencing the ability of Pseudomonas putida strains epI and II to degrade the organophosphate ethoprophos. J. Applied Microbiol., 89: 40-48. PMID: 10945777

Karpouzas, D.G., A. Fotopoulou, U. Menkissoglu-Spiroudi and B.K. Singh, 2005. Non-specific biodegradation of the organophosphorus pesticides, cadusafos and ethoprophos, by two bacterial isolates. FEMS Microbiol. Ecol., 53: 369-378. PMID: 16329956

Kearney, P.C., M.T. Muldoon, C.J. Somich, J.M. Ruth and D.J. Voaden, 1988. Biodegradation of ozonated atrazine as a wastewater disposal system. J. Agric. Food Chem., 36: 1301-1306. DOI: 10.1021/jf00084a044 
Lappin, H.M., M.P. Greaves and J.H. Slater, 1985. Degradation of the herbicide mecoprop [2-(2-methyl-4-chlorophenoxy)propionic acid] by a synergistic microbial community. Applied Environ. Microbiol., 49: 429-433.

Leoni, V., C. Cremisini, R. Giovinazzo, G. Puccetti and M. Vitali, 1992. Activated sludge biodegradation test as a screening method to evaluate persistence of pesticides in soil. Sci. Total Environ., 123-124: 279-289. DOI: 10.1016/0048-9697(92)90153-J

Martinez-Toledo, M.V., V. Salmeron, B. Rodelas, C. Pozo and J. Gonzalez-Lopez. 1998. Effects of the fungicide captan on some functional groups of soil microflora. Applied Soil Ecol., 7: 245-255. DOI: 10.1016/S0929-1393(97)00026-7

Megadi, V.B., P.N. Tallur, S.I. Mulla and H.Z. Ninnekar, 2010. Bacterial degradation of fungicide captan. J. Agric. Food Chem., 58: 12863-12868. DOI: 10.1021/jf1030339

Munch, E.V., P. Lant and J. Keller, 1996. Simultaneous nitrification and denitrification in bench-scale sequencing batch reactors. Water Res., 30: 277-284. DOI: 10.1016/0043-1354(95)00174-3

Ning, J., Z. Bai, G. Gang, D. Jiang and Q. Hu et al., 2010. Functional assembly of bacterial communities with activity for the biodegradation of an organophosphorus pesticide in the rape phyllosphere. FEMS Microbiol. Lett., 306: 135-43. PMID: 20529133

Oerke, E.C. and H.W. Dehne, 2004. Safeguarding production-losses in major crops and the role of crop protection. Crop Protect., 23: 275-285. DOI: 10.1016/j.cropro.2003.10.001

Osteen, C. and M. Livingstion, 2007. Pest Management Practices. In: Agricultural Resources and Environmental Indicators, Wiebe, K.D. and N.R. Gollehon (Eds.). Nova Publishers, New York, ISBN-10: 1600214673,pp: 129-183.

Piotrowska-Seget, Z., R. Engel and E. Nowak Jacek Kozdroj, 2008. Successive soil treatment with captan or oxytetracycline affects non-target microorganisms. World J. Microbiol. Biotechnol., 24: 2843-2848. DOI: $10.1007 /$ s1 1274-008-9815-2

Radianingtyas, H., G.K. Robinson and A.T. Bull, 2003. Characterization of a soil-derived bacterial consortium degrading 4-chloroaniline. Microbiol., 149: 3279-3287. PMID: 14600240

Krishna, K.R. and L. Philip, 2009. Biodegradation of mixed pesticides by mixed pesticide enriched cultures. J. Environ. Sci. Health Part B, 44: 18-30. PMID: 19089711
Rhee, S.K., G.M. Lee, J.H. Yoon, Y.H. Park, H.S. Bae and S.T. Lee, 1997. Anaerobic and aerobic degradation of pyridine by a newly isolated denitrifying bacterium. Applied Environ. Microbiol., 63: 2578-2585. PMCID: PMC168555

Ridgway, R.L., J.C. Tinney, J.T. MacGregor and N.J. Starler, 1978. Pesticide use in agriculture. Environ. Health Perspect., 27: 103-112. DOI: 10.1289/ehp.7827103

Shan, X., L. Junxin, L. Lin and Q. Chuanling, 2009. Biodegradation of malathion by Acinetobacter johnsonii MA19 and optimization of cometabolism substrates. J. Environ. Sci., 21: 76-82. DOI: 10.1016/S1001-0742(09)60014-0

Aldrich, S., 2011. Material Safety Data Sheets. Sigma-Aldrich, Oakville, Ontario.

Swanner, E.D and A.S. Templeton, 2011. Potential for nitrogen fixation and nitrification in the granite-hosted subsurface at henderson mine, CO. Front Microbiol, 2: 254-254. DOI: 10.3389/fmicb.2011.00254

Tuxen, N., H. J. Albrechtsen and P.L. Bjerg, 2006. Identification of a reactive degradation zone at a landfill leachate plume fringe using high resolution sampling and incubation techniques. J. Contaminant Hydrol., 85: 179-194. DOI: 10.1016/j.jconhyd.2006.01.004

Wainwright, M. and G.J.F. Pugh, 1975. Effect of fungicides on the numbers of micro-organisms and frequency of cellulolytic fungi in soils. Plant Soil, 43: 561-572. DOI: $10.1002 /$ jpln.19771400512

Wilson, C. and C. Tisdell, 2001. Why farmers continue to use pesticides despite environmental health and sustainability costs. Ecol. Econ., 39: 449-462. DOI: 10.1016/S0921-8009(01)00238-5

Winterlin, W., J.N. Seiber, A. Craigmill, T. Baier, J. Woodrow and G. Walker. 1989. Degradation of pesticide waste taken from a highly contaminated soil evaporation pit in California. Arch. Environ. Contamination Toxicol., 18: 734-747. DOI: 10.1007/BF01225011

WAKB, 2011. Wolfram Mathematica Chemical Data.

Xiaoqiang, C.H.U., F. Hua, P. Xuedong, W. Xiao and S. Min et al., 2008. Degradation of chlorpyrifos alone and in combination with chlorothalonil and their effects on soil microbial populations. J. Environ. Sci., 20: 464-469. DOI: 10.1016/S1001-0742(08)62080-X 